\title{
Editorial \\ VIII Congresso Internacional de Educação Física e Motricidade Humana XIV Simpósio Paulista de Educação Física
}

\author{
29 de Maio a $1^{\circ}$ de Junho de 2013 \\ Departamento de Educação Física \\ Universidade Estadual Paulista \\ Instituto de Biociências, Rio Claro \\ Wilson do Carmo Junior \\ Presidente da Comissão Organizadora \\ VIII CIEFMH e XIV SPEF
}

\begin{abstract}
O tema central "Prática em Crise: Contra a Educação Física Sedentária” vem de encontro à realidade que nos induz a reflexão sobre o sentido da prática. Mais que um debate sobre um tema, o qual é um chamamento para uma sociedade que caminha para a indolência e acomodação, é um apelo à intelectualidade e a mídia sobre a saúde e a qualidade de vida nos discursos presentes na formação profissional e acadêmica na educação física.
\end{abstract}

Não há como negar que o cenário e o contexto da prática de atividades físicas, esportes, as diferentes modalidades de ginásticas, atividades lúdicas e de aventura, as transformações conceituais da profissão, sobretudo o significado e o sentido da formação profissional, nos provoca para um momento de reflexão.

O tema aqui nesse evento, educação física sedentária, nos fez pensar sobre o sentido pelo qual a prática de exercícios com estilo de vida das pessoas não se sustenta, mediada por uma cultura do conforto, da indolência, da tecnologia para um menor esforço. Esse paradoxo, assistido por uma imensa população que, apesar de sentir a necessidade de se exercitar, praticar esportes, ampliar os conteúdos na educação física escolar, a prática de esportes e exercícios nos projetos de inclusão, redescobrir as atividades de aventura, redirecionar a prática profissional dentro de uma estrutura de mercado em expansão, ainda assim, o projeto educação como atividade cultural, ainda necessita de um choque conceitual. Nesse cenário, entendemos que a prática na qual estamos ancorados há indicativos de que é preciso repensar, bem como fazer uso da arte, da filosofia, da história, da sociologia, da fisiologia, da neurociência, da biomecânica, entre tantas outras áreas do conhecimento, tanto quanto for necessário para compor um quadro interdisciplinar no qual promoveremos o resgate ontológico do sentido das práticas corporais para a cultura.

Esse é o ponto: apresentamos a tese de que esse Congresso constitui um impulso desdobrado cujo foco nos induz a resgatar uma educação física como promoção da vida. Na prática, um exercício de ciência e consciência que nos eleva a compreensão da totalidade da vida —o viver, o viver bem, o viver melhor-responsabilidade de uma área do conhecimento em expansão, um papel renovado cuja intenção é também compreender a totalidade no ser humano.

Sejam todos bem-vindos! 